\title{
USE OF COMMUNICATIVE APPROACH AND THE USE OF IMAGE MEDIA IN IMPROVING WRITING SKILLS
}

\author{
Tuti Nurhayati \\ SD Negeri Cinangsi, Cikalongkulon \\ nurhayatitutii67@gmail.com
}

\begin{abstract}
The communicative approach and use an iamege media without pictorial picture books can be used to improve students' skills in writing essays. The research was conducted using a classroom action research design. Subjects in this study were third grade students of Cinangsi Elementary School, Cikalongkulon District. The study was conducted in two cycles. Data collection uses test and non-test techniques. The test used is a test of action in the form of assignment writing essays, while the non-test technique used is observation, journals, interviews, and photo documentation. The results showed that the average learning outcomes in the first cycle was 73.79, and in the second cycle increased to 88.12. Thus, there was an increase from cycle I to cycle II of $14.33 \%$. This increase in student writing skills is also followed by changes in behavior, from negative behavior to positive behavior. In cycle II, students who were previously less enthusiastic about writing essays became enthusiastic, happy, and interested after participating in learning to write essays with a communicative approach and media without textbooks.
\end{abstract}

Keywords: communicative approach, writing essays

\section{PENDAHULUAN}

Pembelajaran keterampilan berbahasa pada hakikatnya adalah untuk membekali individu dengan keterampilan berkomunikasi. Komunikasi pada dasarnya berfungsi untuk menyampaikan informasi, pengalaman, perasaan, dan pengetahuan. Melalui komunikasi sikap dan perasaan seseorang atau sekelompok orang dapat dipahami oleh pihak lain. Akan tetapi, komunikasi hanya efektif apabila pesan yang disampaikan akan ditafsirkan sama oleh penerima pesan tersebut. Pesan yang disampaikan itu adalah berupa informasi dalam bentuk bahasa.

Pendekatan komunikatif dan media buku bergambar tanpa teks dalam menulis karangan dapat dijadikan sebagai pendekatan dan media untuk mencapai salah satu tujuan pembelajaran mata pelajaran Bahasa dan Sastra Indonesia di SD.

Artikel ini akan mendeskripsikan peningkatan keterampilan menulis karangan siswa kelas III SDN Cinangsi Kecamatan Cikalongkulon, serta perubahan perilaku setelah mengikuti pembelajaran dengan pendekatan komunikatif dan media buku bergambar tanpa teks.

Beberapa peneliti yang membahas tentang kemampuan siswa menulis karangan yaitu penelitian Suryanti (2001), Suryanto (2004), Widyastuti (2004), Rahayu (2006).

Berdasarkan kajian pustaka tersebut, dapat diketahui bahwa kajian mengenai keterampilan menulis karangan dengan berbagai teknik, metode, dan pendekatan telah banyak dilakukan, tetapi penelitian mengenai keterampilan menulis karangan dengan 
pendekatan komunikatif dan media buku bergambar tanpa teks belum pernah dilakukan. Pendekatan komunikatif dan media buku bergambar tanpa teks sengaja dipilih karena dalam pendekatan ini merupakan konsep belajar yang dapat mengembangkan kompetensi siswa yaitu kemampuan menggunakan bahasa yang dipelajarinya untuk berkomunikasi dalam berbagai bentuk situasi dan konteks.

Teori-teori yang digunakan sebagai acuan dalam penelitian meliputi hakikat menulis, tujuan menulis, manfaat menulis, hakikat menulis karangan, media buku bergambar tanpa teks dalam pembelajaran menulis karangan, pendekatan komunikatif dan pendekatan komunikatif dalam pembelajaran menulis karangan.

\section{Hakikat Menulis}

Menurut Tarigan (1994) hakikat keterampilan menulis adalah keterampilan bahasa yang produktif dan ekspresif, berkomunikasi secara tidak langsung, tidak secara tatap muka dengan orang lain. Dalam kegiatan menulis ini, penulis harus terampil memanfaatkan struktur kata, kosa kata, dan grafologi. Keterampilan menulis tidak datang secara otomatis melainkan harus melalui latihan dan praktek yang banyak dan teratur.

Tujuan menulis yaitu memproyeksikan sesuatu mengenai diri seseorang. Menulis tidak hanya memilih pokok pembicaraan yang sesuai, tetapi harus menentukan siapa yang akan membaca tulisan tersebut, serta apa maksud dan tujuan dia menulis (Tarigan 1993:22).

Menurut Akhadiah dkk. (1998:1-2), ada delapan manfaat menulis yaitu (1) penulis dapat mengenali kemampuan dan potensi dirinya, (2) penulis dapat berlatih mengembangkan berbagai gagasan, (3) penulis dapat lebih menyerap, mencari serta menguasai informasi sehubungan dengan topik yang ditulis, (4) penulis dapat terlatih dalam mengorganisasi gagasan secara sistematis serta mengungkapkannya secara tersirat, (5) penulis akan dapat meninjau serta menilai gagasannya sendiri secara lebih objektif, (6) penulis akan lebih mudah memecahkan permasalahan dengan menganalisis permasalahan yang telah tersurat dalam konteks yang lebih konkret, (7) dengan menulis, penulis terdorong untuk secara aktif, dan (8) dengan kegiatan menulis yang terencanakan membiasakan penulis berpikir serta berbahasa secara tertib dan teratur.

\section{Hakikat Karangan}

Karangan adalah susunan kata yang berlapis-lapis dan teratur yang menggunakan bahasa yang teratur pula (Karsana 1986:4). Dalam hal ini karangan juga mempunyai beberapa fungsi, diantaranya yaitu karangan yang memberitahu, karangan yang berfungsi menggambarkan, karangan yang berfungsi mengingatkan, karangan yang berfungsi untuk korespondensi, dan sebagainya (Karsana 1986:17-24)

Sebuah tulisan dikatakan sebagai sebuah karangan apabila memenuhi unsur-unsur pembangun sebuah karangan. Menurut Widyamartaya (1990:9-10), unsur-unsur atau bahan-bahan integral yang membentuk suatu karangan adalah gagasan, penuturan, tatanan dan bahasa.

\section{Pendekatan Komunikatif}

Pendekatan komunikatif adalah pendekatan yang berlandaskan kepada pemikiran bahwa kemampuan menggunakan bahasa dalam komunikasi merupakan tujuan yang harus dicapai dalam pembelajaran bahasa. Pada dasarnya pendekatan komunikatif berorientasi pada fungsi bahasa sebagai alat komunikasi. Tujuan pembelajarannya adalah mengembangkan kompetensi komunikatif yang meliputi kompetensi gramatikal, sosiolinguistik, wacana dan kompetensi strategi. (Savignon 1983 dalam Pringgawidagda 2002: 131) 
Tujuan pembelajaran komunikatif ini adalah untuk mengembangkan kompetensi komunikatif bahasa pada diri pembelajar, untuk menggugah kemampuan belajar siswa, membuat belajar yang menyenangkan dan membantu memudahkan pelaksanaan pembelajaran. Jadi, dengan pendekatan komunikatif diharapkan siswa dapat memperoleh hasil belajar yang lebih baik, baik prestasi belajar maupun kemampuan berpikir aktif dan kreatif dalam belajar.

Dalam kurikulum berbasis isi atau kurikulum 2006 mata pelajaran bahasa dan sastra Indonesia mencakup empat keterampilan yaitu keterampilan menyimak, berbicara, membaca dan menulis. Keempat keterampilan tersebut saling berhubungan. Keterampilan berbicara dan menulis adalah kemampuan produktif, sedangkan keterampilan menyimak dan membaca merupakan kemampuan reseptif. Keempat keterampilan tersebut merupakan target pembelajaran bahasa Indonesia di sekolah, baik pada jenjang pendidikan dasar maupun menengah. Standar kompetensi aspek menulis kelas III adalah mengungkapkan pikiran, perasaan, dan informasi dalam karangan sederhana dan puisi. Kompetensi dasar yang harus dikuasai siswa kelas III adalah menulis karangan sederhana berdasarkan gambar seri menggunakan pilihan kata dan kalimat yang tepat dengan memperhatikan penggunaan ejaan, huruf kapital dan tanda titik.

Untuk meningkatkan keterampilan menulis karangan siswa kelas III SDN Cinangsi Kecamatan Cikalongkulon peneliti menggunakan media buku bergambar tanpa teks sebagai sarana untuk membantu siswa dalam menyampaikan gagasannya.

Buku bergambar tanpa teks merupakan media yang tepat untuk pembelajaran menulis karangan, karena gambar yang kelihatannya diam sebenarnya banyak berkata bagi mereka yang peka dan penuh imajinasi. Pemilihan gambar harus tepat, menarik dan merangsang siswa. Melalui media buku bergambar, siswa dapat dengan bebas mengekspresikan gagasan yang diperoleh, sehingga siswa lebih bebas merinci atau mengurutkan semua peristiwa yang ada di gambar.

\section{METODE}

Penelitian tindakan kelas ini dilakukan dengan dua siklus dalam empat tahap, yakni perencanaan, tindakan, observasi dan refleksi. Pada tahap perencanaan ditentukan langkahlangkah yang akan dilakukan peneliti untuk memecahkan masalah. Rencana kegiatan yang akan dilakukan adalah (1) menyusun rencana pembelajaran menulis karangan menggunakan buku bergambar tanpa teks dengan pendekatan komunikatif, (2) menyiapkan instrumen tes beserta penilaiannya (3) membuat dan menyiapkan instrumen nontes berupa lembar observasi, lembar wawancara, lembar jurnal, dan dokumentasi foto, (4) menyiapkan alat bantu pembelajaran berupa media buku bergambar tanpa teks, dan (5) mengadakan kolaborasi dengan guru wali kelas.

Pada tindakan dilaksanaan pembelajaran yang telah disiapkan. Tindakan yang akan dilakukan peneliti adalah melaksanakan pembelajaran menulis karangan menggunakan buku bergambar tanpa teks dengan pendekatan komunikatif, tindakan ini dilakukan dalam tiga tahap, yaitu pendahuluan, inti dan penutup.

Pada observasi ini, akan diketahui tingkah laku dan aktivitas siswa selama pembelajaran berlangsung, jurnal diberikan untuk mengungkap segala hal yang dirasakan oleh siswa selama mengikuti pembelajaran, dan pendapat siswa yang dilakukan diluar jam pelajaran terhadap perwakilan siswa yang memperoleh nilai tinggi dan rendah.

Subyek penelitian ini adalah siswa SDN Cinangsi Kecamatan Cikalongkulon kelas 3 tahun ajaran 2008/2009. Kelas 3 tersebut terdiri atas 24 siswa, yaitu 10 laki-laki dan 14 perempuan. Peneliti mengambil subjek tersebut dengan alasan berdasarkan hasil wawancara dengan guru wali kelas 3 SDN 
Cinangsi Kecamatan Cikalongkulon, saat ini kondisi kemampuan menulis karangan narasi siswa kelas tersebut masih rendah.

Instrumen penelitian yang digunakan untuk pengumpulan data tes dan nontes. Instrumen tes digunakan untuk mengungkap tingkat keterampilan menulis karangan siswa, sedangkan nontes (lembar observasi, lembar jurnal, lembar wawancara, dan dokumentasi foto) digunakan untuk mengungkap perubahan tingkah laku siswa selama pembelajaran menulis karangan.

Tes yang digunakan dalam penelitian ini adalah tes menulis karangan. Observasi dilakukan untuk mengami perubahan perilaku siswa dalam proses belajar mengajar, sikap positif maupun negatif siswa pada proses belajar mengajar menulis karangan dengan media buku bergambar tanpa teks.

Jurnal dibuat dengan tujuan untuk mengetahui respon siswa terhadap pembelajaran menggunakan media buku bergambar tanpa teks dengan pendekatan komunikatif. Peneliti menyiapkan lembar jurnal siswa dan guru. Jurnal guru berisi uraian pendapat dan seluruh kejadian yang ditangkap guru pengampu selama proses pembelajaran berlangsung. Jurnal siswa berisisi tentang; 1) cara mengajar yang digunakan oleh guru; 2) media buku bergambar tanpa teks dengan pendekatan komunikatif yang digunakan dalam pembelajaran; 3) kesan siswa terhadap pembelajaran menulis karangan; 4) kesulitan yang dialami siswa; dan 5) saran siswa terhadap proses pembelajaran yang akan datang.

Wawancara digunakan untuk mendapat informasi tentang keadaan responden dengan cara tanya-jawab yang berkaitan dengan variabel penelitian. Wawancara dilakukan dengan enam siswa, yaitu dua siswa yang sendapat nilai tertinggi, dua siswa dengan nilai rendah, dan dua siswa dengan nilai sedang di kelasnya.

Teknik analisis data dilakukan secara kuantitatif maupun kualitatif. Uraian tentang teknik kuantitatif dan teknik kualitatif sebagai berikut. Teknik kuantitatif digunakan untuk menganalisis data kuantitatif. Data kuantitatif ini diperoleh dari hasil tes menulis karangan menggunakan buku bergambar tanpa teks dengan pendekatan komunikatif. Nilai dari masing-masing siklus dihitung jumlahnya dalam satu kelas. Teknik kualitatif dipakai untuk menganalisis data kualitatif. Data kualitatif ini diperoleh dari data nontes yaitu observasi, jurnal, dan wawancara.

Hasil analisis siklus I dan siklus II dibandingkan untuk mengetahui perubahan tingkah laku siswa. Dari perbandingan tersebut dapat diketahui tingkat perubahan perilaku siswa.

\section{HASIL DAN PEMBAHASAN}

Pada bab ini disajikan hasil penelitian siklus I dan siklus II yang berupa hasil tes dan nontes. Hasil tes siklus I dan siklus II adalah hasil tes menulis karangan dengan media buku bergambar tanpa teks. Hasil nontes berupa hasil berupa hasil observasi, wawancara, jurnal guru, jurnal siswa.

\section{Hasil Tes Prasiklus}

Hasil tes menulis karangan Berdasarkan tabel dapat diketahui bahwa bobot nilai tes kemapuan siswa dalam menulis pada prasiklus secara klasikal mencapai 1511 dengan nilai rata-rata 62,95 dalam kategori cukup. Belum ada siswa yang berhasil mencapai nilai dalam kategori sangat baik (85-100), sejumlah 6 siswa berhasil mencapai nilai dalam kategori baik (70-84), yakni 29,31\% dan 12 siswa yang mencapai nilai dalam kategori cukup (60-69), yakni 48,58\%. Pada hasil tes prasiklus ada 6 siswa yang mencapai nilai dalam kategori kurang (0-59), yakni $22,11 \%$ dan tidak ada siswa yang mencapai nilai dalam kategori sangat kurang (0-49).

Hasil tes menulis karangan tersebut merupakan gabungan dari 8 aspek kemampuan menulis karangan. Kedelapan aspek tersebut yaitu; (1) Kesesuaian judul dengan 
isi, (2) Rangkaian peristiwa, (3) Pelaku, (4) Setting, (5) Ejaan dan tanda baca, (6) Pilihan kata, (7) Susunan kalimat, (8) Kerapian tulisan. Adapun hasil masing-masing aspek secara rinci dapat dilihat pada uraian berikut ini.

\section{Kesesuaian Judul dengan Isi}

Kesesuaian judul dengan isi artinya ketepatan pemilihan judul yang sesuai dengan isi karangan atau dapat mewakili isi karangan. Skor rata-rata siswa pada aspek ini sebesar 66,6 termasuk kategori cukup. Skor 4 diperoleh apabila judul sesuai dengan karangan. Skor tertinggi (4) berhasil dicapai 3 siswa, yakni sebesar $18,75 \%$ dengan kategori sangat baik. Skor (3) berhasil dicapai 10 siswa dengan kategori baik, yakni sebesar $46,88 \%$ dan skor (2) dengan kategori cukup dicapai oleh 11 siswa, yakni sebesar 34,37\%. Skor terendah (1) dengan kategori kurang pada aspek ini tidak dicapai oleh siswa. Hasil tes menulis karangan pada aspek kesesuaian judul dengan isi dipaparkan pada tabel berikut ini.

\section{Rangkaian peristiwa (alur)}

Aspek kedua adalah rangkaian peristiwa. Skor rata-rata siswa pada aspek ini sebesar 60,4 termasuk dalam kategori cukup. Skor tertinggi (4) berhasil dicapai oleh 4 siswa, yakni sebesar 27,59\%, skor (3) dengan kategori baik dicapai oleh 6 siswa, yakni sebesar $31,03 \%$, skor (2) dalam kategori cukup diperoleh 10 siswa, yakni sebesar $34,48 \%$ dan skor terendah (1) dicapai oleh 4 siswa, yakni sebesar 6,90\%. Hasil tes menulis karangan pada aspek rangkaian peristiwa (alur) dipaparkan pada tabel berikut ini.

\section{Pelaku}

Aspek ketiga ialah pelaku. Skor tertinggi (4) berhasil dicapai oleh 6 siswa dengan kategori sangat baik, yakni sebesar 39,35\%. Skor (3) dengan kategori baik dicapai 7 siswa, yakni sebesar 34,42\% dan skor (2) dengan kategori cukup dicapai oleh 5 siswa, yakni sebesar 16,40\%. Skor terendah (1) pada aspek ini dicapai oleh 1 siswa, yakni sebesar 9,83\% dengan kategori kurang.

\section{Tempat(setting)}

Aspek keempat adalah setting. Skor rata-rata siswa pada aspek ini sebesar 72,91 termasuk kategori baik. Skor tertinggi (4) berhasil dicapai oleh 9 siswa dengan kategori sangat baik, yakni sebesar 53,73\%. Skor (3) dengan kategori baik berhasil dicapai oleh 3 siswa, yakni sebesar $13,43 \%$ dan skor (2) dengan kategori cukup dicapai oleh 10 siswa, yakni sebesar 29,85\%. Skor terendah (1) pada aspek ini dicapai oleh 2 siswa, yakni sebesar $2,99 \%$.

\section{Ejaan dan Tanda baca}

Aspek kelima adalah ejaan dan tanda baca. Skor rata-rata siswa pada aspek ini sebesar 53,12 termasuk kategori kurang. Tidak ada siswa yang mencapai skor (4) dengan kategori sangat baik. Skor (3) berhasil dicapai oleh 5 siswa dengan kategori baik, yakni sebesar 29,41. Skor terendah (1) pada aspek ini dicapai oleh 2 siswa, yakni sebesar 3,92. Skor dengan kategori cukup (2) berhasil dicapai 17 siswa, yakni sebesar 66,67.

\section{Pilihan Kata}

Skor rata-rata siswa pada aspek ini sebesar 60,41 termasuk kategori cukup. Skor tertinggi (4) berhasil dicapai 3 siswa, yakni sebesar 20,69\% dengan kategori sangat baik. Skor (3) berhasil dicapai 6 siswa dengan kategori baik, yakni sebesar 31,04\% dan skor (2) dengan kategori cukup dicapai oleh 13 siswa, yakni sebesar 44,82\%. Skor terendah (1) dengan kategori kurang pada aspek ini dicapai oleh 2 siswa, yakni 3,45\%. Hasil tes menulis karangan pada aspek kesesuaian judul dengan isi dipaparkan pada tabel berikut ini. 


\section{Susunan Kalimat}

Aspek keempat adalah setting. Skor rata-rata siswa pada aspek ini sebesar 57,29 termasuk kategori kurang. Skor tertinggi (4) berhasil dicapai oleh 3 siswa dengan kategori sangat baik, yakni sebesar $21,82 \%$. Skor (3) dengan kategori baik berhasil dicapai oleh 7 siswa, yakni sebesar 38,19\% dan skor (2) dengan kategori cukup dicapai oleh 8 siswa, yakni sebesar $29,09 \%$. Skor terendah (1) pada aspek ini dicapai oleh 6 siswa, yakni sebesar $10,90 \%$. Hasil tes menulis karangan pada aspek susunan kalimat, dipaparkan pada tabel berikut ini.

\section{Kerapian Tulisan}

Aspek kedelapan adalah kerapian tulisan. Skor rata-rata siswa pada aspek ini sebesar 72,91 termasuk kategori baik. Skor tertinggi (4) berhasil dicapai oleh 4 siswa dengan kategori sangat baik, yakni sebesar $22,86 \%$. Skor (3) dengan kategori baik berhasil dicapai oleh 16 siswa, yakni sebesar 68,57\% dan skor (2) dengan kategori cukup dicapai oleh 2 siswa, yakni sebesar 5,71\%. Skor terendah pada aspek ini dicapai oleh 2 siswa, yakni sebesar 2,86\%. Hasil tes menulis karangan pada aspek setting, dipaparkan pada tabel berikut ini.

Berdasarkan uraian hasil menulis karangan pada prasiklus diperoleh kesimpulan bahwa nilai klasikal menulis karangan siswa kelas III SDN Cinangsi Kecamatan Cikalongkulonmencapai kategori cukup, yakni 62,85 . Nilai klasikal yang belum mencapai nilai ketuntasan belajar, yakni 70,00 akan ditingkatkan pada siklus I. Pada prasiklus ada tiga aspek yang perlu diperhatikan dan ditingkatkan yaitu aspek ejaan, pilihan kata dan pilihan kalimat yang termasuk dalam kategori kurang. Ketiga aspek tersebut merupakan faktor tersulit yang dicapai oleh siswa. Hal tersebut dapat dibuktikan dengan banyaknya kesalahan dalam penggunaan EYD, terutama dalam penggunaan huruf kapital dan tanda baca. Siswa mengalami kesulitan dalam memilih kata dan menyusun kalimat karena belum terbiasa untuk menulis karangan ketiga aspek tersebut akan ditingkatkan dan diperbaiki pada siklus I dengan menggunakan media buku bergambar tanpa teks.

\section{Hasil Siklus I}

Penelitian siklus I dilaksanakan satu kali pertemuan yaitu pada tanggal 29 Mei 2017. Hasil penelitian pada siklus I melalui hasil tes dan nontes. Siklus I merupakan pemberlakuan tindakan awal penelitian kemampuan menulis karangan dengan menggunakan buku bergambar tanpa teks. Hasil penelitian menulis karangan siklus I secara lengkap dapat dilihat pada tabel berikut ini.

Berdasarkan perhitungan dapat diketahui bahwa bobot nilai tes kemampuan siswa dalam menulis karangan pada siklus I secara klasikal mencapai 1743 dengan nilai rata-rata $73,79 \%$, termasuk dalam kategori baik. Sebanyak 4 siswa berhasil mencapai nilai dalam kategori sangat baik (85-100), sejumlah 9 siswa berhasil mencapai nilai dalam kategori baik (70-84), kategori cukup (60-69) dicapai 9 siswa, 2 siswa termasuk dalam kategori kurang (50-59) dan tidak ada siswa yang mencapai nilai dalam kategori kurang (0-49).

\section{Kesesuaian Judul dengan Isi}

Kesesuaian judul dengan isi artinya ketepatan pemilihan judul yang sesuai dengan isi karangan atau dapat mewakili isi karangan. Skor rata-rata siswa pada aspek ini sebesar 75 termasuk kategori baik. Skor 4 diperoleh apabila judul sesuai dengan karangan. Skor tertinggi (4) berhasil dicapai 8 siswa, yakni sebesar $44,45 \%$ dengan kategori sangat baik. Skor (3) berhasil dicapai 9 siswa dengan kategori baik, yakni sebesar 37,5\% dan skor (2) dengan kategori cukup dicapai oleh 6 siswa, yakni sebesar 16,67\%. Masih ada 1 siswa dengan skor terendah (1) dengan kategori kurang. Hasil tes menulis karangan pada aspek kesesuaian judul dengan isi dipaparkan pada tabel berikut ini. 


\section{Rangkaian peristiwa (alur)}

Aspek kedua adalah rangkaian peristiwa. Skor rata-rata siswa pada aspek ini sebesar 70,8 termasuk dalam kategori baik. Skor tertinggi (4) berhasil dicapai oleh 8 siswa, yakni sebesar $47,05 \%$, skor (3) dengan kategori baik dicapai oleh 4 siswa, yakni sebesar 17,65\% , skor (2) dalam kategori cukup diperoleh 12 siswa, yakni sebesar $35,30 \%$ dan tidak ada siswa yang mencapai skor (1), Hasil tes menulis karangan pada aspek rangkaian peristiwa (alur) dipaparkan pada tabel berikut ini.

\section{Pelaku}

Aspek ketiga ialah pelaku. Skor tertinggi (4) berhasil dicapai oleh 13 siswa dengan kategori sangat baik, yakni sebesar $68,42 \%$. Skor (3) dengan kategori baik dicapai 2 siswa, yakni sebesar 7,90\% dan skor (2) dengan kategori cukup dicapai oleh 9 siswa, yakni sebesar 23,68\%. Tidak ada siswa yang mendapat skor terendah (1) dengan kategori kurang. Hasil tes menulis karangan pada aspek pelaku dipaparkan pada tabel berikut ini.

\section{Tempat (setting)}

Aspek keempat adalah setting. Skor rata-rata siswa pada aspek ini sebesar 76,04 termasuk kategori baik. Skor tertinggi (4) berhasil dicapai oleh 10 siswa dengan kategori sangat baik, yakni sebesar 54,80\%. Skor (3) dengan kategori baik berhasil dicapai oleh 5 siswa, yakni sebesar 20,54\% dan skor (2) dengan kategori cukup dicapai oleh 9 siswa, yakni sebesar 24,66\%. Skor terendah (1) pada aspek ini tidak dicapai oleh siswa. Hasil tes menulis karangan pada aspek setting, dipaparkan pada tabel berikut ini.

\section{Ejaan dan Tanda baca}

Aspek kelima adalah ejaan dan tanda baca. Skor rata-rata siswa pada aspek ini sebesar 67,70 termasuk kategori cukup. Lima siswa berhasil mencapai skor (4) dengan kategori sangat baik, yakni sebesar 30,77. Skor (3) berhasil dicapai oleh 8 siswa dengan kategori baik, yakni sebesar 36,93. Skor terendah (1) pada aspek ini dicapai oleh 1 siswa, yakni sebesar 1,53. Skor dengan kategori cukup (2) berhasil dicapai 10 siswa, yakni sebesar 30,77.

\section{Pilihan Kata}

Skor rata-rata siswa pada aspek ini sebesar 68,75 termasuk kategori cukup. Skor tertinggi (4) berhasil dicapai 7 siswa, yakni sebesar $42,42 \%$ dengan kategori sangat baik. Skor (3) berhasil dicapai 5 siswa dengan kategori baik, yakni sebesar 22,73\% dan skor (2) dengan kategori cukup dicapai oleh 11 siswa, yakni sebesar 33,34\%. Skor terendah (1) dengan kategori kurang pada aspek ini dicapai oleh 1 siswa, yakni 1,51\%. Hasil tes menulis karangan pada aspek pilihan kata dipaparkan pada tabel berikut ini.

\section{Susunan Kalimat}

Aspek keempat adalah setting. Skor rata-rata siswa pada aspek ini sebesar 70,83 termasuk kategori baik. Skor tertinggi (4) berhasil dicapai oleh 6 siswa dengan kategori sangat baik, yakni sebesar 35,29\%. Skor (3) dengan kategori baik berhasil dicapai oleh 10 siswa, yakni sebesar $44,11 \%$ dan skor (2) dengan kategori cukup dicapai oleh 6 siswa, yakni sebesar 17,65\%. Skor terendah (1) pada aspek ini dicapai oleh 2 siswa, yakni sebesar 2,95\%. Hasil tes menulis karangan pada aspek susunan kalimat, dipaparkan pada tabel berikut ini.

\section{Kerapian Tulisan}

Aspek kedelapan adalah kerapian tulisan. Skor rata-rata siswa pada aspek ini sebesar 77,08 termasuk kategori baik. Skor tertinggi (4) berhasil dicapai oleh 4 siswa dengan kategori sangat baik, yakni sebesar 27,03\%. Skor (3) dengan kategori baik berhasil dicapai oleh 16 siswa, yakni sebesar 64,87\% dan skor (2) dengan kategori cukup 
dicapai oleh 3 siswa, yakni sebesar 8,10\%. Tidak ada siswa mencapai skor terendah (1) pada aspek ini. Hasil tes menulis karangan pada aspek kerapian tulisan, dipaparkan pada tabel berikut ini.

Berdasarkan uaraian hasil menulis karangan pada siklus I diperoleh simpulan bahwa nilai klasikal menulis karangan siswa kelas III SDN Cinangsi Kecamatan Cikalongkulon berhasil mencapai kategori baik, yakni 73,79. Kenaikan nilai klasikal tersebut membuktikan bahwa ada peningkatan kemampuan siswa dalam menulis karangan setelah mengalami pembelajaran dengan media buku bergambar tanpa teks. Hasil yang sudah baik ini belum memuaskan karena masih ada 2 siswa yang termasuk dalam kategori kurang dan jumlah siswa yang mendapat nilai dalam kategori sangat baik belum mencapai $75 \%$ dari jumlah siswa yang ada dikelas.

Hasil tes siklus I yang belum memuaskan akan ditingkatkan lagi pada pembelajaran menulis karangan siklus II dengan melakukan beberapa perbaikan. Pada siklus I ada 3 aspek yang perlu diperhatikan dan ditingkatkan yaitu aspek penggunaan EYD, pilihan kata dan susunan kalimat. Pada siklus I ketiga faktor tersebut merupakan faktor tersulit yang dihadapi siswa dalam menulis karangan. Hal tersebut dapat dibuktikan dengan cukup banyak kesalahan dalam penggunaan huruf kapital dan tanda baca. Sedangkan pada pilihan kata yang digunakan masih kurang tepat, dan dalam menyusun kalimat masih kurang padu artinya antara kalimat satu dengan kalimat yang lain tidak saling berhuhungan sehingga tidak menghasilkan suatu makna.

Siswa mengalami kesulitan karena mereka kurang memperhatikan penjelasan guru dan kurang serius dalam mengikuti pembelajaran serta cenderung pasif untuk bertanya kepada guru. Pada siklus II akan dilakukan perbaikan pada ketiga aspek tersebut dengan memperhatikan faktor-faktor yang menyebabkan siswa kurang memperhatikan pembelajaran yang sedang berlangsung.

\section{Hasil Nontes Siklus I}

Hasil penelitian nontes pada siklus I ini didapatkan dari hasil observasi, jurnal siswa dan jurnal guru yang disertai dengan dokumentasi foto sebagai tanda bukti. Hasil selengkapnya dijelaskan pada uraian berikut ini.

\section{Hasil Observasi}

Berdasarkan observasi yang dilakukan dapat diketahui bahwa $31,82 \%$ siswa cukup aktif bertanya dan menjawab pertanyaan guru selama proses pembelajaran menulis karangan. Hal ini dikarenakan siswa termotivasi dan keingintahuan yang besar terhadap buku bergambar tanpa teks yang digunakan sebagai media dalam pembelajaran menulis karangan.

\section{Hasil Jurnal Siswa dan Jurnal Guru}

Berdasarkan jurnal siswa, sebanyak 24 siswa atau $100 \%$ menyatakan senang dengan cara mengajar guru yang disertai dengan media buku bergambar tanpa teks, sabar, sopan, jelas, dan ramah. Sebanyak 21 siswa atau $87,36 \%$ mengungkapkan bahwa mereka merasa senang dengan materi menulis karangan karena dapat membantu mereka menguasai kemampuan menulis karangan, sedangkan 3 siswa atau 12,56\% menyatakan materi menulis karangan ialah materi yang susah. Dalam hal kemampuan menulis karangan setelah mengalami pembelajaran pada siklus I, sebanyak 20 siswa atau 83,27\% menyatakan masih kesulitan untuk menulis karangan dan 4 siswa atau $16,73 \%$ menyatakan tidak merasa kesulitan.

\section{Hasil Wawancara}

Berdasarkan wawancara yang dilakukan terhadap keenam siswa tersebut dapat diketahui bahwa semua siswa merasa senang dengan pembelajaran menulis karangan. Mereka sebelumnya belum pernah 
mendapatkan pembelajaran menulis karangan dengan menggunakan buku bergambar tanpa teks.

Mereka menyatakan bahwa adanya media buku bergambar tanpa teks mempermudah mereka dalam mengembangkan ide ketika menulis karangan. Setelah mengalami pembelajaran selama siklus I, siswa menyatakan bahwa mereka merasa kesulitan, terutama dalam hal penggunaan tanda baca.

\section{Refleksi Siklus I}

Pada siklus I ini pembelajaran menulis karangan menggunakan buku bergambar tanpa teks. Dalam pembelajaran menulis karangan guru (peneliti) menerapkan pendekatan komunikatif. Pendekatan komunikatif ini guru akan menjelaskan makna dari rangkaian peristiwa dalam buku bergambar tanpa teks, apabila siswa masih merasa kesulitan dapat bertanya kepada guru.

Proses pembelajaran pada siklus I yang masih kurang optimal ini akan diperbaiki pada tindakan pada siklus II. Dalam siklus II ini peneliti akan menekankan pada hasil tes siklus I, pengalaman belajar siswa, pengelolaan kelas dengan cara mendekati siswa pada waktu mengerjakan tugas menulis karangan secara berkelompok, dan kedisiplinan guru dalam pengelolaan waktu. Pembelajaran pada siklus II ini juga dibuat semenarik mungkin supaya siswa menjadi lebih aktif dan bersemangat.

\section{Hasil Tes Menulis Karangan Siklus II}

Tindakan pada siklus II dilaksanakan untuk meningkatkan hasil tes yang diperoleh pada siklus I yang telah mencapai kategori baik, yakni sejumlah 4 siswa atau sebesar 19,32\%, sejumlah 9 siswa atau sebesar 40,14\% mendapat nilai dalam kategori baik, kategori cukup sebesar 33,88\% sejumlah 9 siswa dan 2 siswa masih dalam kategori kurang.
Pada siklus II peneliti berkeinginan untuk meningkatkan lagi jumlah siswa yang mendapat nilai dalam kategori baik,sangat baik dan cukup sehingga tidak ada lagi siswa yang mendapat nilai dalam kategori kurang yang diperoleh pada siklus I.

Pada siklus II ini penelitian dilakukan dengan rencana dan persiapan yang lebih matang dibandingkan dengan siklus I. Adanya perbaikan pada pengelolaan kelas, siswa dibagi dalam empat kelompok agar dapat saling bertukar pikiran dan saling membantu apabila teman dalam satu kelompok mengalami kesulitan, selain itu guru juga mendekati siswa pada waktu mengerjakan tugas menulis karangan dan membuat variasi dalam pembelajaran tanpa mengabaikan pendekatan komunikatif, maka diharapkan hasil penelitian yang berupa tes kemampuan menulis karangan mengalami peningkatan dalam hal kuantitasnya.

Berdasarkan data dapat diketahui bahwa bobot nilai tes kemampuan siswa dalam menulis karangan pada siklus II secara klasikal mencapai 2115 dengan nilai rata-rata 88,12 termasuk dalam kategori sangat baik. Sebanyak 13 siswa telah berhasil mencapai nilai dalam kategori sangat baik, yakni $56,50 \%$ dan sebanyak 11 siswa termasuk dalam kategori baik, yakni 43,50\%. Hasil ini merupakan peningkatan yang cukup memuaskan.

Hasil tes menulis karangan merupakan gabungan dari 8 aspek kemampuan menulis karangan dengan media buku bergambar tanpa teks. Kelima aspek tersebut yaitu; (1) Kesesuaian judul dengan isi, (2) Rangkaian peristiwa, (3) Pelaku, (4) Setting, (5) Ejaan dan tanda baca, (6) Pilihan kata, (7) Susunan kalimat, (8) Kerapian tulisan. Adapun hasil masing-masing aspek secara rinci dapat dilihat pada uraian berikut ini.

\section{Kesesuaian Judul dengan Isi}

Kesesuaian judul dengan isi artinya ketepatan pemilihan judul yang sesuai dengan 
isi karangan atau dapat mewakili isi karangan. Skor rata-rata siswa pada aspek ini sebesar 94,79 termasuk kategori sangat baik. Skor 4 diperoleh apabila judul sesuai dengan karangan. Skor tertinggi (4) berhasil dicapai 20 siswa, yakni sebesar 87,91\% dengan kategori sangat baik. Skor (3) berhasil dicapai 3 siswa dengan kategori baik, yakni sebesar 9,90\% dan skor (2) dengan kategori cukup dicapai oleh 1 siswa, yakni sebesar 2,19\%. Tidak ada siswa dengan skor terendah (1) dengan kategori kurang. Hasil tes menulis karangan pada aspek kesesuaian judul dengan isi dipaparkan pada tabel berikut ini.

\section{Rangkaian peristiwa (alur)}

Aspek kedua adalah rangkaian peristiwa. Skor rata-rata siswa pada aspek ini sebesar 85,41 termasuk dalam kategori sangat baik. Skor tertinggi (4) berhasil dicapai oleh 12 siswa, yakni sebesar $58,53 \%$, skor (3) dengan kategori baik dicapai oleh 10 siswa, yakni sebesar 36,59\%, skor (2) dalam kategori cukup diperoleh 2 siswa, yakni sebesar 4,88\% dan tidak ada siswa yang mencapai skor (1), Hasil tes menulis karangan pada aspek rangkaian peristiwa (alur) dipaparkan pada tabel berikut ini.

\section{Pelaku}

Aspek ketiga ialah pelaku. Skor tertinggi (4) berhasil dicapai oleh 15 siswa dengan kategori sangat baik, yakni sebesar 85,41 Skor (3) dengan kategori baik dicapai 4 siswa, yakni sebesar $14,64 \%$ dan skor (2) dengan kategori cukup dicapai oleh 5 siswa, yakni sebesar 12,19\%. Tidak ada siswa yang mendapat skor terendah (1) dengan kategori kurang. Hasil tes menulis karangan pada aspek pelaku dipaparkan pada tabel berikut ini.

\section{Tempat (setting)}

Aspek keempat adalah setting. Skor rata-rata siswa pada aspek ini sebesar 91,6 termasuk kategori sangat baik. Skor tertinggi (4) berhasil dicapai oleh 13 siswa dengan kategori sangat baik, yakni sebesar 59,09\%. Skor (3) dengan kategori baik berhasil dicapai oleh 10 siswa, yakni sebesar 34,09\% dan skor (2) dengan kategori cukup dicapai oleh 3 siswa, yakni sebesar 6,82\%. Skor terendah (1) pada aspek ini tidak dicapai oleh siswa. Hasil tes menulis karangan pada aspek setting, dipaparkan pada tabel berikut ini.

\section{Ejaan dan Tanda baca}

Aspek kelima adalah ejaan dan tanda baca. Skor rata-rata siswa pada aspek ini sebesar 82,29 termasuk kategori baik. Sebanyak 12 siswa berhasil mencapai skor (4) dengan kategori sangat baik, yakni sebesar $60,76 \%$. Skor (3) berhasil dicapai oleh 7 siswa dengan kategori baik, yakni sebesar 26,59. Skor terendah (1) pada aspek ini tidak dicapai oleh siswa. Skor dengan kategori cukup (2) berhasil dicapai 5 siswa, yakni sebesar $12,65 \%$.

\section{Pilihan Kata}

Skor rata-rata siswa pada aspek ini sebesar 83,33 termasuk kategori baik. Skor tertinggi (4) berhasil dicapai 13 siswa, yakni sebesar $65 \%$ dengan kategori sangat baik. Skor (3) berhasil dicapai 6 siswa dengan kategori baik, yakni sebesar 22,5\% dan skor (2) dengan kategori cukup dicapai oleh 5 siswa, yakni sebesar 12,5\%. Skor terendah (1) dengan kategori kurang pada aspek ini tidak dicapai oleh siswa. Hasil tes menulis karangan pada aspek pilihan kata dipaparkan pada tabel berikut ini.

\section{Susunan Kalimat}

Aspek keempat adalah setting. Skor rata-rata siswa pada aspek ini sebesar 85,41 termasuk kategori sangat baik. Skor tertinggi (4) berhasil dicapai oleh 14 siswa dengan kategori sangat baik, yakni sebesar 68,29\%. Skor (3) dengan kategori baik berhasil dicapai oleh 6 siswa, yakni sebesar 21,95\% dan skor (2) dengan kategori cukup dicapai oleh 4 siswa, yakni sebesar 9,76\%. Skor terendah pada aspek ini tidak dicapai oleh siswa. Hasil 
tes menulis karangan pada aspek susunan kalimat, dipaparkan pada tabel berikut ini.

\section{Kerapian Tulisan}

Aspek kedelapan adalah kerapian tulisan. Skor rata-rata siswa pada aspek ini sebesar 88,54 termasuk kategori sangat baik. Skor tertinggi (4) berhasil dicapai oleh 15 siswa dengan kategori sangat baik, yakni sebesar 70,59\%. Skor (3) dengan kategori baik berhasil dicapai oleh 7 siswa, yakni sebesar 24,71\% dan skor (2) dengan kategori cukup dicapai oleh 2 siswa, yakni sebesar 4,70\%. Tidak ada siswa mencapai skor terendah (1) pada aspek ini.

Berdasarkan uraian hasil menulis karangan pada siklus II diperoleh simpulan bahwa nilai klasikal menulis karangan pada siswa kelas III SDN Cinangsi Kecamatan Cikalongkulon berhasil mencapai kategori sangat baik, yakni 88,12 Kenaikan nilai klasikal tersebut membuktikan bahwa terjadi peningkatan yang sangat memuaskan karena $56,50 \%$ siswa telah berhasil mencapai nilai dalam kategori sangat baik dan 11 siswa berhasil mencapai nilai dalam kategori baik, yakni $43,50 \%$.

Pada siklus II tidak terdapat lagi siswa yang mendapat nilai dalam kategori cukup, kurang maupun sangat kurang dan faktor tersulit yang masih dihadapi siswa telah ada peningkatan meskipun tidak banyak. Aspek penggunaan EYD telah berhasil mencapai skor 82,29 dalam kategori baik. Peningkatan tersebut karena pada siklus II dilakukan pembelajaran yang mampu menarik perhatian siswa dan mampu membangkitkan semangat siswa dalam mengikuti pembelajaran. Pada siklus II peneliti membacakan contoh hasil karangan yang akan dikerjakan siswa, sehingga siswa mendapat gambaran tentang isi karangan yang akan dibuat.

\section{Hasil Nontes Siklus II}

Hasil penelitian nontes pada siklus II ini didapatkan dari hasil observasi jurnal siswa dan jurnal guru, dan wawancara. Hasil selengkapnya pada uraian berikut ini.

\section{Observasi}

Berdasarkan hasil observasi, dapat diketahui bahwa hampir seluruh siswa sudah aktif mengikuti kegiatan selama proses pembelajaran berlangsung. Hal ini karena guru menerapkan strategi baru dalam pembelajaran menulis karangan pada siklus II ini.

Guru menjelaskan rangkain peristiwa di dalam buku bergambar tanpa teks sehingga siswa lebih mudah memahami isi dari buku bergambar tanpa teks tersebut. Guru membagi kelas menjadi empat kelompok dan masingmasing kelompok terlihat antusias mengerjakan tugas menulis karangan. Strategi ini ternyata mampu meningkatkan perhatian siswa dalam mengikuti pembelajaran menulis dan mampu meningkatkan kesungguhan siswa dalam mengerjakan tugas dari guru.

Setelah kegitan menulis karangan selesai terlihat peningkatan yang cukup memuaskan. Berdasarkan pengelompokan tersebut dapat disimpulkan bahwa sebagian besar siswa sudah paham dalam menulis karangan.

Aktivitas setelah selesai menulis karangan ialah membacakan hasil karangan di depan kelas. Dalam kegitan ini yang mempresentasikan hasil karangan adalah perwakilan beberapa siswa dalam satu kelas.

Pada siklus II ini, terjadi peningkatan dalam perilaku positif siswa. Siswa yang pada siklus I masih malu-malu bertanya sudah tidak malu-malu lagi, siswa yang tidak berani membacakan hasil karangannya sudah tidak canggung lagi, dan siswa lebih serius lagi dalam mengerjakan tugas dari guru. Guru merasakan bahwa sebagian besar siswa sudah bisa menikmati pembelajaran menulis karangan dengan santai. 
Berdasarkan hasil observasi tersebut secara keseluruhan dapat disimpulkan bahwa perilaku negatif siswa sudah banyak mengalami perubahan menuju pada perilaku positif. Sebagian besar siswa sudah mampu mengikuti pembelajaran dengan baik. Keadaan itu tentu saja merupakan sesuatu hal yang sangat diharapkan karena peneliti sudah berusaha secara maksimal untuk merubah pola pembelajaran menjadi lebih santai dan menyenangkan.

\section{Jurnal Siswa dan Guru}

Berdasarkan jurnal siswa, sebanyak 24 siswa atau $100 \%$ menyatakan senang dengan cara mengajar guru yang disertai dengan media buku bergambar tanpa teks, sabar, sopan, jelas, dan tidak galak. Sebanyak 20 siswa atau 83,27\% mengungkapkan bahwa mereka merasa senang dengan materi menulis karangan karena dapat membantu mereka menguasai kemampuan menulis karangan, sedangkan 4 siswa atau 16,73\% menyatakan materi menulis karangan ialah materi yang susah. Dalam hal kemampuan menulis karangan setelah mengalami pembelajaran pada siklus I dan siklus II, sebanyak 14 siswa atau 54,55\% menyatakan masih kesulitan untuk menulis karangan dan 10 siswa atau $45,45 \%$ menyatakan tidak merasa kesulitan lagi.

Saat pembelajaran menulis karangan siswa menjadi lebih aktif jika dibandingkan pada siklus I. Pada siklus II ini siswa tidak mau lagi untuk bertanya dan menjawab pertanyaan guru. Situasi kelas sudah kondusif sehingga proses belajar mengajar berlangsung dengan baik dan siswa merasa lebih bersemangat. Sementara itu pengelolaan kelas dan pengelolaan waktu yang dilakukan guru sudah baik.

Berdasarkan wawancara yang dilakukan terhadap keenam siswa tersebut dapat diketahui bahwa semua siswa merasa senang dengan pembelajaran menulis karangan. Mereka sebelumnya belum pernah mendapatkan pembelajaran menulis karangan dengan menggunakan buku bergambar tanpa teks seperti yang dibelajarkan oleh peneliti. Mereka menyatakan bahwa adanya media buku bergambar tanpa teks mempermudah mereka dalam menguasai kemampuan menulis karangan. Setelah mengalami pembelajaran selama dua siklus, siswa menyatakan bahwa mereka sudah tidak merasa sulit lagi dan sudah dapat menulis karangan dengan benar.

\section{Refleksi Siklus II}

Pelaksanaan pembelajaran menulis dengan media buku bergambar tanpa teks pada siklus II secara keseluruhan sudah baik. Pada siklus ini siswa lebih memahami materi mengenai menulis karangan, siswa menjadi lebih aktif dan kreatif. Siswa tidak malu lagi dalam bertanya dan tidak takut lagi dalam menjawab pertanyaan dari guru (peneliti). Hal ini dikarenakan siswa sudah mengenal pola pembelajaran yang diterapkan guru (peneliti).

Pembelajaran yang menyenangkan dan bermakna membuat siswa tidak terbebani saat proses pembelajaran berlangsung. Guru memberikan pujian pada siswa yang memperoleh nilai terbaik I dan II dalam menulis karangan sehingga siswa menjadi lebih bersemangat lagi dalam mengikuti pembelajaran serta bersungguh-sungguh dalam mengerjakan tes menulis karangan yang ditugaskan guru.

\section{Pembahasan}

Pada subbab pembahasan ini dijelaskan pembahasan mengenai peningkatan kemampuan siswa dalam menulis karangan dan perubahan perilaku siswa setelah mengikuti pembelajaran dengan menggunakan buku bergambar tanpa teks.

\section{Kemampuan Siswa}

Pembahasan hasil penelitian didasarka pada hasil prasiklus, siklus I dan siklus II, yaitu berupa data tes dan nontes. Pembahasan hasil tes penelitian mengacu pada 
pemerolehan skor yang dicapai siswa ketika ditugaskan untuk menulis karangan.

Berdasarkan data yang ada dapat disimpulkan bahwa pembelajaran menulis karangan dari prasiklus ke siklus I mengalami peningkatan. Hal ini dibuktikan dengan bertambahnya kuantitas siswa yang mendapat nilai dalam kategori sangat baik dan baik serta berkurangnya siswa yang mendapat nilai dalam kategori cukup dan kurang.

Kemampuan menulis karangan pada rentang nilai 85-100 untuk kategori sangat baik mengalami peningkatan sebesar 19,32\%, rentang nilai 70-84 dalam kategori baik meningkat $10,83 \%$, rentang nilai 60-69 dalam kategori cukup mengalami peningkatan sebesar $14,7 \%$, dan untuk rentang nilai 50-59 dalam kategori kurang mengalami peningkatan sebesar 15,54\% dan untuk rentang nilai $<50$ dalam kategori sangat kurang tidak dicapai oleh siswa.

Pembelajaran menulis karangan dari siklus I ke siklus II mengalami peningkatan cukup tinggi. Hal ini dibuktikan dengan bertambahnya kuantitas siswa yang mendapat nilai dalam kategori sangat baik, yakni $37,18 \%$ siswa dapat meraih nilai dalam kategori sangat baik. Pada rentang nilai 85100 untuk kategori sangat baik mengalami peningkatan sebesar $37,18 \%$, rentang nilai 70-84 dalam kategori baik meningkat 3,36\%, rentang nilai 60-69 dalam kategori cukup, rentang nilai 50-59 dalam kategori kurang dan rentang nilai $<50$ dalam kategori sangat kurang tidak dicapai oleh siswa.

Langkah selanjutnya, diadakan tes menulis karangan oleh guru. Hasil tes menulis karangan prasiklus, siklus I, dan siklus II kemudian direkap. Hasil tes menulis karangan tiap aspek dapat dilihat pada tabel berikut ini.

Berdasarkan rekapitulasi data hasil tes kemampuan menulis karangan dari prasiklus ke siklus I, dapat dijelaskan bahwa kemampuan siswa pada setiap aspek penilaian menulis mengalami peningkatan. Pada aspek kesesuaian judul dengan isi terjadi peningkatan sebesar 10,42. Pada aspek rangkaian peristiwa terjadi peningkatan sebesar 10,4.

Peningkatan sebesar 15,62 terjadi pada aspek pelaku, peningkatan sebesar 3,13 terjadi pada aspek setting, peningkatan sebesar 14,58 terjadi pada aspek ejaan dan tanda baca. Pada aspek pilihan kata terjadi peningkatan sebesar 15,63. Pada aspek susunan kalimat terjadi peningkatan sebesar 13,54 dan peningkatan sebesar 4,17 terjadi pada aspek kerapian tulisan. Hal tersebut menunjukkan bahwa kesalahan siswa dalam semua aspek sudah berkurang.

Kemampuan menulis karangan siklus I ke siklus II, dapat disimpulkan bahwa kemampuan siswa pada setiap aspek penilaian menulis mengalami peningkatan. Pada aspek Pada aspek kesesuaian judul dengan isi terjadi peningkatan sebesar 19,79. Pada aspek rangkaian peristiwa terjadi peningkatan sebesar 14,61. Peningkatan sebesar 6,25 terjadi pada aspek pelaku, peningkatan sebesar 15,56 terjadi pada aspek setting, peningkatan sebesar 14,59 terjadi pada aspek ejaan dan tanda baca. Pada aspek pilihan kata terjadi peningkatan sebesar 14,58. Pada aspek susunan kalimat terjadi peningkatan sebesar 11,46 dan peningkatan sebesar terjadi pada aspek kerapian tulisan. Hal tersebut menunjukkan bahwa kesalahan siswa dalam semua aspek sudah berkurang.

\section{Perilaku Siswa}

Peningkatan kemampuan siswa dalam menulis ini diikuti pula dengan adanya perubahan perilaku siswa dari siklus I sampai siklus II. Berdasarkan data hasil nontes yaitu melalui observasi, jurnal guru, wawancara dan dokumentasi foto pada siklus I dapat disimpulkan bahwa kesiapan siswa dalam megikuti pembelajaran menulis karangan menggunakan media buku bergambar tanpa teks dengan pendekatan komunikatif kurang memuaskan. 
Sebagian besar siswa masih menunjukkan perilaku negatif dalam mengikuti seluruh rangkaian kegiatan dalam proses pembelajaran. Hal ini dibuktikan dengan beberapa siswa yang terlihat ramai dan kurang bersemangat dalam mengikuti pembelajaran.

Berdasarkan serangkaian analisis data dan situasi pembelajaran seperti di atas dapat dijelaskan bahwa perilaku siswa dalam pembelajaran menulis karangan mengalami perubahan yang mengarah pada perilaku positif yaitu siswa semakin aktif dan lebih bersemangat. Suasana kelas pun berubah menjadi lebih aktif dan lebih hidup. Kegiatan mengamati, mengekplorasi, dan berinteraksi dengan model pembelajaran tidak lagi menjadi hal yang menyusahkan bagi siswa.

Dengan demikian, dapat disimpulkan bahwa belajar dengan menggunakan media buku bergambar tanpa teks adalah sangat baik karena dapat membantu siswa dalam menulis karangan dan memberikan pengetahuan yang lebih mengenai menulis karangan kepada siswa. Siswa memiliki pengalaman mengenai menulis karangan yang dapat digunakan untuk menambah pengetahuan.

\section{SIMPULAN}

Kemampuan siswa kelas III SDN Cinangsi Kecamatan Cikalongkulon setelah mengikuti pembelajaran dengan menggunakan buku bergambar tanpa teks mengalami peningkatan. Hasil prasiklus menunjukkan bahwa rata-rata nilai yang dicapai oleh siswa sebesar 62,95 atau $62,95 \%$. Hasil tes siklus I menunjukkan bahwa rata-rata nilai yang dicapai sebesar 73,79 atau 73,79\%. Hal tersebut menunjukkan bahwa terjadi peningkatan sebesar 10,84 atau 10,84\% dari prasiklus ke siklus I.

Pada siklus II rata-rata nilai klasikal sebesar 88,12 atau 88,12\%. Hal tersebut menunjukkan bahwa terjadi peningkatan sebesar 14,33 atau 14,33\% dari siklus I ke siklus II. Hasil tes prasiklus, siklus I, siklus II menunjukkan bahwa pembelajaran menulis karangan dengan media buku bergambar tanpa teks terbukti mampu meningkatkan kemampuan siswa kelas III SDN Cinangsi Kecamatan Cikalongkulon dalam menulis karangan.

Perilaku siswa kelas III SDN Cinangsi Kecamatan Cikalongkulon setelah mengikuti pembelajaran menulis dengan menggunakan buku bergambar tanpa teks mengalami perubahan. Perilaku-perilaku siswa ini dapat dibuktikan dengan data nontes yang meliputi observasi, jurnal siswa dan jurnal guru, dan wawancara pada siklus I dan siklus II

Berdasarkan data observasi pada siklus I kegiatan pembelajaran siswa terlihat kurang bersemangat. Sebagian siswa masih bingung dan belum dapat menyesuaikan diri dengan media pembelajaran yang diterapkan peneliti yaitu pembelajaran menulis karangan dengan media buku bergambar tanpa teks. Selain itu, siswa kurang terlihat konsentrasi dan kurang bersemangat dalam mengikuti pembelajaran.

Pada siklus II terjadi perubahan perilaku siswa ke arah yang lebih baik. Siswa terlihat lebih aktif dan bersemangat dalam mengikuti pembelajaran yang diterapkan guru. Hal tersebut dapat diketahui dari peningkatan respon positif yang ditunjukkan siswa. Sikap siswa sebagian besar sudah mampu menyesuaikan diri dan berkonsentrasi pada pembelajaran yang diterapakan peneliti.

Dengan demikian, dapat disimpulkan bahwa pembelajaran menulis karangan dengan media buku bergambar tanpa teks dapat meningkatkan perilaku positif siswa dan dapt mengurangi perilaku negatif siswa menuju ke arah yang lebih baik.

Berdasarkan simpulan hasil penelitian tersebut, beberapa saran yang dapat dikemuakan sebagai berikut ini.

Para guru bahasa indonesia dapat menggunakan media buku bergambar tanpa teks pada pembelajaran menulis karangan 
karena terbukti dapat mendorong siswa untuk aktif berpikir dan meningkatkan kemampuan siswa dalam menulis karangan. Kepada para pemerhati akademik, khususnya bidang pendidikan bahasa Indonesia, penelitian ini bisa dijadikan bahan penelitian lanjutan.

\section{DAFTAR PUSTAKA}

Akhadiah, dkk. 1998. Pembinaan Kemampuan Menulis Bahasa Indonesia. Jakarta: Erlangga.

Arsyad, Ashar. 20002. Media Pembelajaran. Jakarta: PT Raja Grafindo Persada Budimeong.2008. Inisiasi Pembelajaran Bahasa Indonesia sd 3.pdf.http:// files. wordpers.com

Firdaus. 2008. Firdau's Blog. http:// ww3.yuwie.com (diunduh 06/03/2009) Gie, The Liang. 2002. Terampil Mengarang. Yogyakarta: Andi offset.

Hafid, Abdul. 2002. Buku Bergambar sebagai Sumber Belajar Apresiasi Cerita di Kelas Rendah $S D$. http: //id. Word press.com/ buku bergambar. (diunduh 06/03/2009)

Nurjamin,Asep.2008. Pendekatan Komunikatif dalam Pembelajaran Bahasa. ./pertemuan-ipendekatan-.komunikatif.html.blogspot.com. (diunduh 06/03/2009)

Nursisto. 2000. Penuntun Mengarang. Yogyakarta: Adicita.

Pringgawidagda, Suwarna. 2002. Strategi Penguasaan Berbahasa. Yogyakarta: Adi Citra Karya Nusa.

Rahayu. 2006. Peningkatan Keterampilan Menulis Karangan Narasi Siswa Kelas VII A SMP Negeri 1 Limpung Kabupaten Batang melalui Teknik Menulis Buku Harian. Skripsi: Universitas Negeri Semarang.

Sabana dan Sunarti. 2004. Strategi Belajar Mengajar Bahasa Indonesia. Bandung: Pustaka Setia.

Soeparno. 1988. Media Pengajaran Bahasa. Yogyakarta: Intan Pariwara.

Suparno. 2007. Keterampilan Dasar Menulis. Jakarta: UT

Suryanti. 2001. Peningkatan Keterampilan Menulis Karangan Narasi melalui Teknik Reka Cerita Gambar pada Siswa Kelas II SLTP Negeri 1 Gembong Kabupaten Pati Tahun Ajaran 2000/2001. Skripsi: Universitas Negeri Semarang.

Suryanto. 2004. Peningkatan Keterampilan Menuls Karangan Narasi dengan Teknik Modeling Pada Siswa Kelas II D SLTP Negeri 1 Sukorejo Kendal. Skripsi: Universitas Negeri Semarang

Tarigan, Henry Guntur. 1986. Menulis sebagai Keterampilan Berbahasa. Bandung: Angkasa. 